J. Environ. Sci.

Institute of Environmental Studies and Research - Ain Shams University

\title{
ECONOMIC AND ENVIRONMENTAL STUDY FOR OPTIMAL CROP PATTERN \\ IN THE LIGHT OF THE EXPECTED WATER RESTRECTIONS
}

\author{
Essam M. Ahmed ${ }^{(1)}$; Mosad E. Ragab ${ }^{(2)}$; Seham A. Abdel-Hamid ${ }^{(3)}$ \\ and Mohye M. A. Omar ${ }^{(4)}$
}

1) Planning Sector, Ministry of Water Resources and Irrigation 2) Faculty of Agriculture, Ain Shams University 3) Institute of Environmental studies and Research, Ain Shams University 4) Nile Research Institute, NCWR

\begin{abstract}
The agricultural area in Egypt is the largest consumer of water and still requires more water to expand. Any changes in Nile water supply due to climate change would threaten the agricultural water productivities, both physical productivity and economic productivity, and the food security in Egypt. The objective of the current paper is to investigate the impacts of Nile supply reduction on the agricultural water productivities and food security in Egypt using the Agriculture Sector Model in Egypt (ASME). The results showed that the reduction in Nile supply will either increase or decrease the areas of different crops, and generally will decrease the total cropped area. Regarding the food security, all indicators refer to a slight decline in the food Security progress in terms of reduction of water availability, self-sufficiency of strategic food crops, and net virtual water import. The reduction in Nile supply will also deteriorate the economic situation, which can be confirmed by the reduction in agricultural productivity, consumer-producer surplus, and number of jobs as well as the increase in net imports' value and water marginal value. The current study recommends implementing adaptation measures to efficiently use the available water resources and to increase the agricultural productivity per unit area.
\end{abstract}

Keywords: ASME, agricultural productivity, climate change 


\section{INTRODUCTION}

The actual current water resources available in Egypt are 55.5 Billion Cubic Meter per year (BCM/yr) from the Nile River, 1.3 BCM/yr from effective rainfall on the northern strip of the Mediterranean Sea and Sinai, 2.4 BCM from non-renewable deep groundwater for western desert and Sinai, and $6.5 \mathrm{BCM} / \mathrm{yr}$ from shallow groundwater. The total water supply is 59.7 $\mathrm{BCM}$, while the total current water requirement for different sectors is 79.5 $\mathrm{BCM} / \mathrm{yr}$. The gap between the demand and availability of water is about 13.8 $\mathrm{BCM} / \mathrm{yr}$. This gap is compensated by recycling of drainage water either officially or unofficially. The agricultural sector in Egypt is the largest consumer of water which consumes about $85 \%$ of the total withdrawal.

In addition to its large demand, the agricultural area in Egypt still requires more water to expand. The main problem facing this sector is the possibility of Nile supply change due to climate change phenomenoen. Many studies showed significant changes in the Nile flow due to temperature and precipitation changes. Conway and Hulme (1996) estimated that future flow in the Blue Nile in 2025 could range between an increase of $15 \%$ and a decrease of 9\%. Strzepek et al., (2001) estimated the 2020 flow into the High Aswan Dam (HAD) could decrease by 10 to 50\% (Beyene et al., 2010). El-

Shamy, Wheater (2009c) used bias-corrected statistical downscaling of 17 general circulation models (GCMs) to estimate an average reduction in flow of the Blue Nile of $15 \%$ by the end of the century and a range of change between a decrease of $60 \%$ and an increase of $45 \%$ was provided. Moussa, Omar (2017) showed that the expected release from HAD in 2050 will be 
reduced to $93.2 \%$ and $84.7 \%$ of the current release based on two different emission scenarios.

The process of water resources management requires planning tools to assess different strategies and planning alternatives with respect to both; supply and demand. In Egypt, there are a set of databases and models which have been used as tools for simulation of the water resource system, and for assessment of impacts of different management alternatives. Omar (2013) used the River Basin Simulation (RIBASIM) model to simulate the water resources system in Fayoum Governorate, Egypt. Various scenarios were evaluated in optimistic, moderate and pessimistic conditions. Omar, Moussa (2016) used the Water Evaluation and Planning (WEAP) model for assessment of different scenarios in the year 2025 by implementing different water sufficiency measures. Omar (2016) investigated the possibility of using the LIBRA simulation game to simplify the process of water resources planning in the agricultural sector in Egypt and to assess of impacts of different measures on water demand of the agricultural sector in Egypt. Moussa, Omar (2017) developed a Water Balance Model (WB Model) to study the influence of Nile flow changes due to climate change on the water balances of Egyptian governorates, and to conduct the sensitivity analyses of adaptation measures reducing the expected water shortages.

The Agricultural Sector Model for Egypt (ASME) has been developed since 1977 for evaluating alternative water allocation options in terms of their impacts on cropping patterns, domestic consumption, foreign trade and employment. In 1997, the model was extended and updated to make it 
compatible with the other DSS tools used by National Water Resources Plan to include included programming of an extensive number of data consistency checks, expanding the number of agricultural regions, and replacing the animal husbandry section (NWRP, 1997).

The main expected future challenge facing the water resources system in Egypt is the reduction in Nile supply as a climate change impact. Moussa, Omar (2017) found that the climate change will have 20 possible flows at Dongola station upstream Nasser Lake. Then, they simulated the operation in Nasser Lake and investigated the impacts of two releases, being 93.2\% and $84.7 \%$ of the current release, on the water resources systems of Egyptian governorates. This will definitely cause conflicts among the users of agricultural sector at each governorate and among the Egyptian governorates. Therefore, the objective of current paper is to investigate the impacts of Nile supply reduction on the agricultural water productivities, both physical productivity and economic productivity in Egypt using the Agriculture Sector Model in Egypt (ASME).

\section{MATERIALS AND METHODS}

\section{ASME description:}

ASME is a static partial equilibrium model for simulation of the Egyptian agricultural sector. It matches domestic demand for final crop and livestock commodities and exports, with crop and livestock production, agroprocessing, and imports. The simulation is driven by maximising welfare expressed as the consumer-producer surplus plus the net revenues from international trade under the constraints on the availability of land and 
irrigation water (Nile, deep groundwater and desalination). Irrigation water availability assumes priority for municipal and industrial uses and takes into account the reuse of both irrigation and wastewater. Because ASME is a partial equilibrium model, commodity prices are endogenous (generated by the model) and depend on supply and demand, but import and export prices are exogenous. The model is non-linear, as the objective function is quadratic.

In ASME a complete separation of data and model is maintained, making is rather safe to update the dataset without disturbing the model and to ensure that the various scenarios use the same dataset, making the results fully comparable. ASME distinguishes the following final and intermediate crop and livestock commodities:

i) Crop commodities for direct use: Barley, citrus (representing all tree crops), fava beans, groundnuts, other legumes (fenugreek, chickpea, lupins), lentils, maize (grain), onions, sesame, sorghum (grain), soybean, tomatoes, vegetables (cabbage, cucumber, peas, squash).

ii) Crop commodities as processing input: Flax (unprocessed), paddy (unmilled rice), long \& extra long staple seed cotton (lint \& seeds), sugarbeet, sugarcane, sesame, soybean, wheat (grain), groundnuts.

iii)Crop commodities as processing output: Vegetable oil (from soybean, sesame, cotton seed, groundnut, linseed), sugar (from sugarcane and sugar beet), ginned extra long staple cotton, ginned long staple cotton, flax fibres, wheat flour, rice (milled paddy).

iv)Crop commodities, crop and processing by-products as feed components: Maize stalks without cobs, dry wheat straw, dry barley straw, dry rice 
straw, fava bean crop residues, groundnut haulms, lentil crop residues, vegetable crop residues, fresh sugarcane tops, fresh sugar beet leaves, rice \& wheat bran, decorticated cotton seed cake, soya cake, groundnut cake, linseed \& sesame cake, sugar beet molasses, sugarcane molasses, dried sugar beet

v) Livestock commodities: Industrial processing milk, buffalo milk, cattle milk, veal, fattener beef \& chilled import beef, sheep \& goat meat, poultry eggs, poultry meat.

These crops can be grown in the model at the traditional planting times, one month earlier and one month later. The yields for the early (E) and normal $(\mathrm{O})$ planting are taken as the normal yields, the yield of the late $(\mathrm{L})$ planting are assumed to be 5\% lower. For water application the optimal and three reduced levels are considered (10, 15 and 20\%). The yield reductions caused by the reduced water applications are calculated with Key factors (Annex 0). This implies that for each crop (and separately for each region), twelve variants are considered by the model, each with its specific yield, resulting in a maximum of 372 cropping options per region. For climatic, agronomic and policy reasons, not all crops are grown in all regions.

ASME also considers the following livestock activities: poultry broiler meat production, commercial cattle dairy production (producing cow milk or fat corrected buffalo milk suitable for industrial processing), fattening of yearlings on forage \& concentrate for meat, poultry layer egg production, yearling rearing for meat or fattening, semi-intensive buffalo dairy production (not for modern processing), semi-intensive cattle dairy production (not for modern processing), fattening of yearlings on straw \& concentrate for meat, 
sheep \& goat meat production, traditional buffalo and cattle breeding (including donkeys, ducks, etc.), weaner rearing for meat or rearing. These activities can be carried out using conventional or modern methods of feeding, where applicable. Fourteen different animal feed mixes are distinguished. These mixes are prepared from green fodders, crop and processing residues and grains, and can be used fresh, dry, conserved or treated, as applicable.

\subsection{ASME Water Balance}

The water balance for Nile water as used in ASME is presented schematically in Figure 1. Nile water is released from the High Aswan Dam (HAD) and is conveyed through the Nile, its Delta branches and a large number of irrigation canals. Water is used on a priority basis for municipal and industrial purposes. The remainder is available for agriculture and fish ponds; some water flows directly to the sea to facilitate the use of a shipping lock. Evaporation from open water and from fallow land is considered. 


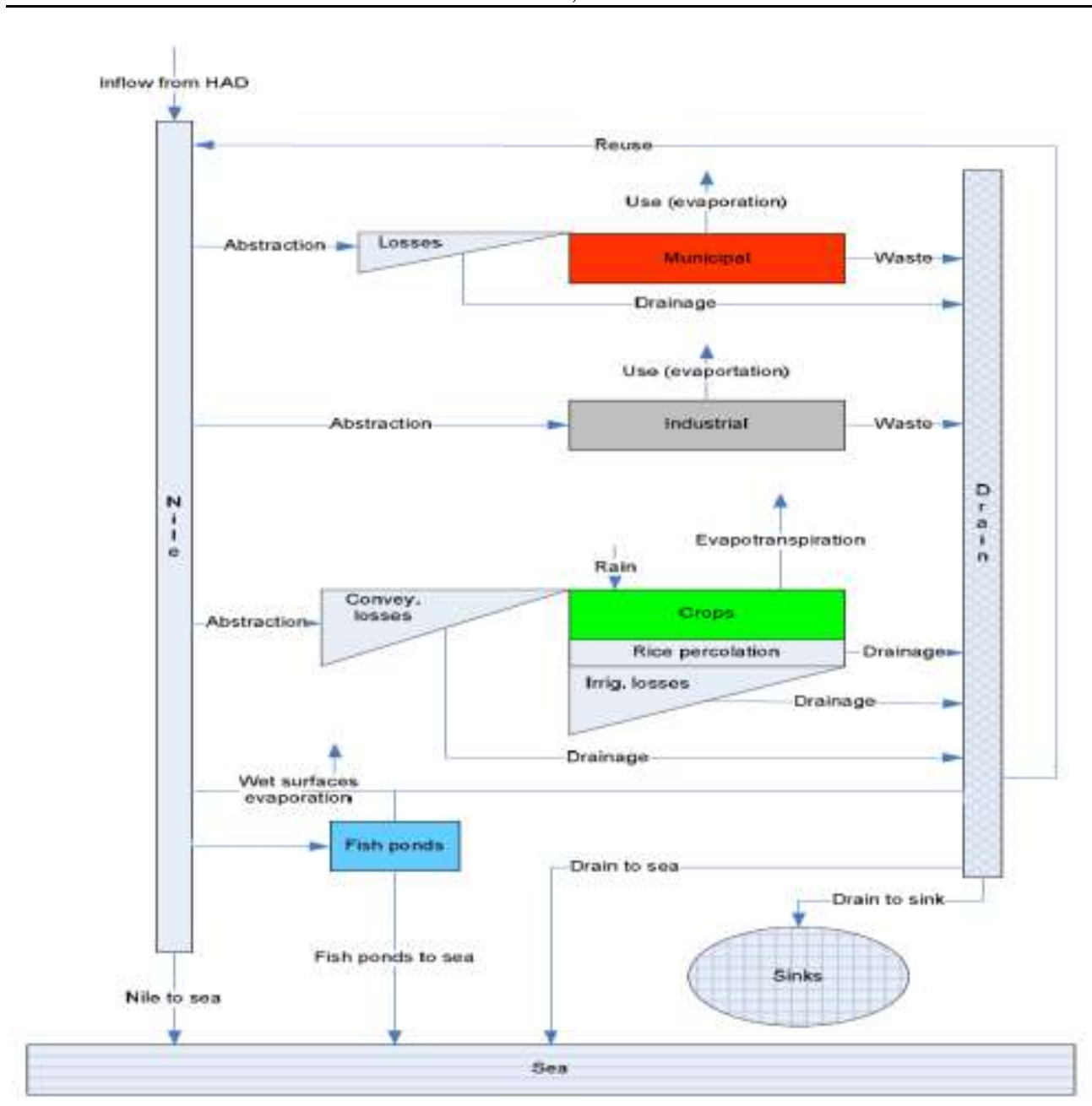

Figure 1: Scheme water balance in ASME

Regional municipal water use in ASME is determined externally and is based on the abstractions of the Holding Companies for Drinking Water and Sanitation. Actual use consists of evaporation; a large proportion of the water abstracted enters the drains as (treated) wastewater, some is lost in desert sinks. The production and conveyance losses are drained. Regional industrial water use is determined externally and entered in ASME. Actual use consists 
of evaporation; a large proportion of the water abstracted enters the drains as (treated) wastewater. Agricultural water use consists of evapotranspiration of the crops. Some of this evapotranspiration is covered by effective rainfall. Conveyance losses in the mesqa and irrigation losses at field level generate drainage. In paddy cultivation extra percolation water is required, which also generates drainage. Agricultural use (net of rain) and losses are abstracted from the Nile system and are calculated in ASME on a governorate level. Wet surfaces (Nile, irrigation and drainage canals, fish ponds) evaporate water. This evaporation is estimated at national level and is distributed proportionally over the regions. Some Nile water flows directly to the sea; an ecological minimum is prescribed together with losses caused by the operation of shipping locks.

Municipal, industrial and agricultural drainage water can return by gravity or though reuse pumping stations to the Nile or irrigation system, or drain to the sea or to sinks (Toshka depression, Lake Qarun, Wadi Rayan). These drainage destinations depend on the location of the region and are entered in ASME as fractions per region. The water of the fish ponds are assumed to drain directly to the sea.

ASME also calculates a deep groundwater balance, showing the available deep groundwater, the effective rainfall, agricultural, municipal and industrial consumption, fallow land evaporation and drainage to sinks. This applies only for deep groundwater, which is used in the governorates New Valley (NVALLEY), Matruh (MATRUH) Red Sea (REDSEA) and South Sinai (SSINAI). 


\section{Nile Supply Scenarios}

Based on the predicted Nile water supply in the year 2050, ASME model will present the cropping pattern in all Egyptian governorates. The current study used the results of (Moussa, Omar 2017) which predicted the expected releases from High Aswan Dam (HAD) due to climate change in the year 2050

They collected the results of 20 scenarios which have been run by five global circulation models (GCMs) for investigating the surface water at the entrance of Nasser Lake in Dongola Station. The percentages of changes in flows at Dongola Station ranged from 75 to $114 \%$ of the current flow. They ignored the percentages exceeding or approaching 100\%. They also ignored the percentages with extreme reductions. They selected only two scenarios being 81 and $92 \%$ which represented average values.

Then, they applied the BlueM model to simulate Nasser Lake operation and predict the expected releases from High Aswan Dam (HAD). They found that the climate change will reduce the Nile water supply to 93.2 and $84.7 \%$ of the current release.

Therefore, the current investigations produced three scenarios based on three different HAD releases being; 55.5 (current), 51.8 and $47.1 \mathrm{BCM} /$ year. Table 1 presents the main characteristics for all scenarios including the available volumes of deep groundwater and desalinated water, population number, urbanization rates, and irrigable areas by both Nile water and deep groundwater. 
J. Environ. Sci.

Institute of Environmental Studies and Research - Ain Shams University

Table 1: Main input characteristics for three scenarios

\begin{tabular}{|l|c|c|c|c|}
\hline Scenario & Unit & $\mathbf{1}$ & $\mathbf{2}$ & $\mathbf{3}$ \\
\hline \hline Available Nile water (HAD release) & BCM & 55.5 & 51.8 & 47.1 \\
\hline Available deep ground water & BCM & 3 & 3 & 3 \\
\hline Available desalinated water & BCM & 0.18 & 0.18 & 0.18 \\
\hline Population number & Million & 90.04 & 90.04 & 90.04 \\
\hline Urbanization rate & Ratio & 0.42 & 0.42 & 0.42 \\
\hline Irrigable area by Nile water & 1000 fed. & 8366 & 8366 & 8366 \\
\hline Irrigable area by Deep Groundwater & 1000 fed. & 449.7 & 449.7 & 449.7 \\
\hline
\end{tabular}

\section{RESULTS}

Based on the available Nile supply (HAD release), rainfall, and the net consumptive use of each crop, ASME presented the cropped areas in the entire country for the three scenario. Table 2 shows the area of each crop and the total cropped area in the three scenarios.

It is obvious that the cropped area of winter onion, sugar beet and winter tomatoes has increased in both future scenarios. In addition, they were higher in scenario 3 than in scenario 2 when HAD release decreased. However, the cropped areas of Orchards, Faba bean, Flax, Groundnut, Long berseem, Lentil, Summer Maize, Other legumes, Summer Onion, Rice, Nili Potato, Summer Potato, Soybeans and Sunflower, Sugar Cane, Nili Sorghum, Summer Sorghum, Nili Tomato, Summer Tomato, Nile Vegetables, Summer Vegetables and Wheat decreased in both future scenarios with less area in scenario 3. The cropped areas of Barley, short berseem, Nili Maize, cotton and sesame fluctuated irregularly with the HAD release reduction. The total 
cropped area decreased in both future scenarios and it was less in scenario 3 when HAD release decreased.

Table 3 shows different indicators regarding the food security situation in the three scenarios. The challenge of increasing food supply is mainly dependent on water availability. It is clear that the water availability per capita decreased as a result of HAD release reduction as in scenarios 2 and 3 . The yearly amount of water allocated for agricultural sector decreased when HAD release decreased. Moreover, the actual agricultural water consumption excluding water losses also decreased with the HAD release reduction. The overall efficiency of agricultural sector decreased with the HAD release reduction.

The cropping intensity index, the fraction of the cultivated area that is harvested, also decreased when HAD release decreased. The self-sufficiency of both wheat and cereals decreased with the reduction in HAD release. Regarding the concept of virtual water, the amount of imported virtual water was independent on HAD release, since it increased from scenario 1 to 2 and then decreased from scenario 2 to 3 . However, exporting water products was affected by the reduction in HAD release, as the amount of virtual water export increased. The net amount of virtual water import decreased as a result of HAD release reduction. 
J. Environ. Sci.

Institute of Environmental Studies and Research - Ain Shams University

Table 2: Crops' areas in the three scenarios

\begin{tabular}{|l|c|c|c|c|}
\hline \multirow{2}{*}{ Scenario } & \multirow{2}{*}{ Unit } & \multicolumn{3}{|c|}{ Supplies } \\
\cline { 3 - 5 } & & $\mathbf{( 5 5 . 5}$ BCM) & $\mathbf{( 5 1 . 8 ~ B C M )}$ & $\mathbf{( 4 7 . 1 B C M})$ \\
\hline Barley & $1000 \mathrm{fed}$. & 108.21 & 113.85 & 111.77 \\
\hline Orchards & $1000 \mathrm{fed}$. & 126.33 & 116.6 & 116.96 \\
\hline Faba bean & $1000 \mathrm{fed}$. & 75.64 & 62.1 & 70.15 \\
\hline Flax & $1000 \mathrm{fed}$. & 0 & 0 & 0 \\
\hline Groundnut & $1000 \mathrm{fed}$. & 23.3 & 22.51 & 23.09 \\
\hline Long berseem & $1000 \mathrm{fed}$. & 1427.14 & 1390.58 & 1151.03 \\
\hline Lentil & $1000 \mathrm{fed}$. & 300.92 & 214.83 & 119.28 \\
\hline Nili Maize & $1000 \mathrm{fed}$. & 524.23 & 472.65 & 585.67 \\
\hline Summer Maize & $1000 \mathrm{fed}$. & 452.35 & 461.33 & 370.33 \\
\hline Other legumes & $1000 \mathrm{fed}$. & 18.1 & 17.93 & 17.44 \\
\hline Summer Onion & $1000 \mathrm{fed}$. & 10.77 & 9.85 & 6.07 \\
\hline Winter Onion & $1000 \mathrm{fed}$. & 6.76 & 7.68 & 11.8 \\
\hline Rice & $1000 \mathrm{fed}$. & 1459.96 & 1442.92 & 1402.22 \\
\hline Nili Potato & $1000 \mathrm{fed}$. & 176.66 & 168.04 & 166.37 \\
\hline Summer Potato & $1000 \mathrm{fed}$. & 0 & 0 & 0 \\
\hline Soybeans and Sunflower & $1000 \mathrm{fed}$. & 2343.04 & 2281.53 & 2250.1 \\
\hline Sugar Beet & $1000 \mathrm{fed}$. & 175.61 & 353.43 & 697.22 \\
\hline Short berseem & $1000 \mathrm{fed}$. & 958.11 & 973.4 & 804.18 \\
\hline Sugar Cane & $1000 \mathrm{fed}$. & 395.22 & 290.98 & 0 \\
\hline Cotton & $1000 \mathrm{fed}$. & 300.34 & 292.7 & 302.23 \\
\hline Sesame & $1000 \mathrm{fed}$. & 107.4 & 103.08 & 108.41 \\
\hline Nili Sorghum & $1000 \mathrm{fed}$. & 339.4 & 238.13 & 199.53 \\
\hline Summer Sorghum & $1000 \mathrm{fed}$. & 0 & 0 & 0 \\
\hline Nili Tomato & $1000 \mathrm{fed}$. & 349.92 & 123.29 & 104.33 \\
\hline Summer Tomato & $1000 \mathrm{fed}$. & 116.83 & 91.42 & 89.88 \\
\hline Winter Tomato & $1000 \mathrm{fed}$. & 117.42 & 242.41 & 255.18 \\
\hline Nile Vegetables & $1000 \mathrm{fed}$. & 617.19 & 612.1 & 605.72 \\
\hline Summer Vegetables & $1000 \mathrm{fed}$. & 208.96 & 207.27 & 206.41 \\
\hline Winter Vegetables & $1000 \mathrm{fed}$. & 218.65 & 216.97 & 219.9 \\
\hline Wheat & $1000 \mathrm{fed}$. & 2468.23 & 2224.29 & 2124.39 \\
\hline Total cropped area & $1000 \mathrm{fed}$. & 13426.69 & 12751.88 & 12120.45 \\
\hline & & & & \\
\hline
\end{tabular}


Table 3: Food security situation in the three scenarios

\begin{tabular}{|l|c|c|c|c|}
\hline Scenario & Unit & $\mathbf{1}$ & $\mathbf{2}$ & $\mathbf{3}$ \\
\hline \hline Water availability per capita & $\mathrm{m} 3$ & 665.35 & 624.37 & 572.34 \\
\hline Agricultural water extracted from Nile & $\mathrm{BCM}$ & 58.03 & 53.29 & 46.65 \\
\hline Agricultural water consumption & $\mathrm{BCM}$ & 31.46 & 28.75 & 25.02 \\
\hline Overall system efficiency Nile & $\%$ & 58.61 & 57.56 & 55.39 \\
\hline Cropping intensity index & $\%$ & 165.36 & 156.5 & 146.34 \\
\hline Wheat self-sufficiency & $\%$ & 42.21 & 38.54 & 36.97 \\
\hline Rice self-sufficiency & $\%$ & 100 & 100 & 100 \\
\hline Average cereal self-sufficiency & $\%$ & 59.32 & 57 & 56.75 \\
\hline Virtual water import & $\mathrm{BCM}$ & 18.56 & 18.72 & 18.11 \\
\hline Virtual water export & $\mathrm{BCM}$ & 0.47 & 0.41 & 0.26 \\
\hline Net virtual water import & $\mathrm{BCM}$ & 18.09 & 18.32 & 17.85 \\
\hline
\end{tabular}

The evaluation of economic situation of agricultural sector in the three scenarios depends on many aspects including; values of agricultural productivity, consumer-producer surplus, number of jobs, net imports' value and water marginal value (Table 4). The net value of agricultural productivity at farm gate prices decreased when HAD release decreased.

The consumer-producer surplus is an important indicator for evaluation of the economic progress of agricultural sector. The consumer-producer surplus is calculated as the difference between the total crops' revenue and the combined costs of crops' harvesting and irrigation. The surplus decreases with the reduction in HAD release.

The number of jobs in the agricultural and agro-industrial sector also decreased. The net value of agricultural imports increased as a result of HAD release reduction, which negatively affects the economic situation. Finally, the marginal value of water is based on its scarcity. The HAD release 
reduction clearly leads to an increase in the marginal values of water. This is an indication that the water becomes scarce.

Table 4: Economic situation in the three scenarios

\begin{tabular}{|l|c|c|c|c|}
\hline Scenario & Unit & $\mathbf{1}$ & $\mathbf{2}$ & $\mathbf{3}$ \\
\hline $\begin{array}{l}\text { Net value of agricultural productivity at } \\
\text { farm gate prices }\end{array}$ & Billion & 215.52 & 210.56 & 207.85 \\
\hline $\begin{array}{l}\text { Net value of agricultural productivity per } \\
\text { feddan at farm gate prices }\end{array}$ & LE/fed & 24447.03 & 23884.86 & 23577.75 \\
\hline Consumer-producer surplus & BLE & 1598.13 & 1597.02 & 1594.47 \\
\hline $\begin{array}{l}\text { Number of agricultural and agro- } \\
\text { industry jobs }\end{array}$ & M jobs & 254.06 & 242.98 & 220.08 \\
\hline Net value of agricultural imports & BLE & 39.03 & 41.31 & 41.51 \\
\hline Marginal value of water & LE/m3 & 0.22 & 0.38 & 0.83 \\
\hline
\end{tabular}

\section{DISCUSSION}

When the HAD release decreases, the production areas of winter onion, sugar beet and winter tomatoes increase. However, the cropped areas of Orchards, Faba bean, Flax, Groundnut, Long berseem, Lentil, Summer Maize, Other legumes, Summer Onion, Rice, Nili Potato, Summer Potato, Soybeans and Sunflower, Sugar Cane, Nili Sorghum, Summer Sorghum, Nili Tomato, Summer Tomato, Nile Vegetables, Summer Vegetables and Wheat decrease. The cropped areas of Barley, short berseem, Nili Maize, cotton and sesame are independent on the HAD release. It is clear that the total cropped area decreases when HAD release deceases.

The HAD release has negative impacts on the food security in the country. All indicators refer to a slight decline in the food security progress in terms of reduction of water availability, self-sufficiency of strategic food crops, and net virtual water import. 
The reduction in HAD release deteriorates the economic situation in the agricultural sector. This can be confirmed by the observable reduction in agricultural productivity, consumer-producer surplus, and number of jobs as well as the increase in net imports' value and water marginal value.

\section{CONCLUSION AND RECOMMENDATION}

The current study predicted the influence of the change in HAD release due to climate change phenomenon on the agricultural sector in Egypt in the year 2050 using the ASME model. The current investigations are based on results of two scenarios for HAD release presented by (Omar, Moussa, 2016) being; $93.2 \%$ and $84.7 \%$ of the current release. When the HAD release decreases, the cropped areas of the majority of crops decrease, while the areas of few crops increase. Few crops also are independent on the HAD release. The total cropped area decreases when HAD release deceases. The food security progress declines, since there is a reduction in water availability, selfsufficiency of strategic food crops, and net virtual water import. There is also deterioration in the economic situation in terms of the reduction in agricultural productivity, consumer-producer surplus, and number of jobs as well as the increase in net imports' value and water marginal value.

\section{REFERENCES}

Arab Republic of Egypt, Ministry of Water Resources and Irrigation/Planning Sector. Country Strategy: National Water Resources Plan Egypt; 1997.

Beyene, T.; Lettenmaier, D. and Kabat, P, (2009), Hydrologic impacts of climate change on the Nile River Basin: implications of the 2007 IPCC scenarios. Climatic Change, 100(3): 433 - 461. 
Conway, D.; and Hulme, M, (1996), The Impacts Of Climate Variability And Future Climate Change In The Nile Basin On Water Resources In Egypt, International Journal of Water Resources Development, 13(3): 277-296.

Elshamy, M. E. and Wheater, H.S, (2009), Performance assessment of a GCM land surface scheme using a fine-scale calibrated hydrological model: An evaluation of MOSES for the Nile Basin. Hydrol. Process. 23, 1548-1564 .

M. (2014). Evaluation of Actions for Better Water Supply and Omar, Demand Management in Fayoum, Egypt Using RIBASIM. Water Science Journal -, 27 (2014) 78 - 90

M. Omar (2016). Improvement of Water Resources Planning in Egypt's Omar, Agricultural Sector Using the LIBRA-River Basin Simulation Game. i-Explore International Research Journal Consortium International Journal of IT, Engineering and Applied Sciences Research (IJIEASR) Volume: 5, No.: 2, 1 - 7

Moussa, A. M. A. and Omar, E. D. M. (2017). Impacts of Climate Change on Water Balances at the Governorates level in Egypt. Nile Water Science \& Engineering Journal (ISSN: 2090 - 0953) Volume: 9, Issue No.: 1, 25- 37.

Omar, E .D .M. and Moussa, A. M. A. (2016). Water Management in Egypt for Facing the Future Challenges, Journal of Advanced Research (2016) 7, $403-412$

Strzepek, K. M.; Yates, D. N., Yohe, G., Tol, R., and Mader, N, (2001), Constructing NotImplausible Climate and Economic Scenarios for Egypt, Kluwer Academic Publishers. Printed in the Netherlands, Integrated Assessment 2: 139 - 157. 


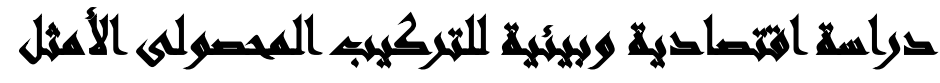

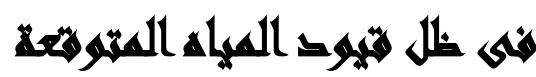

\section{[०]}

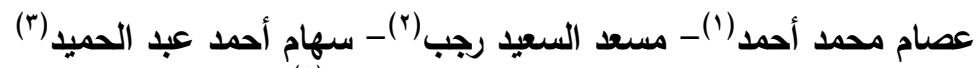

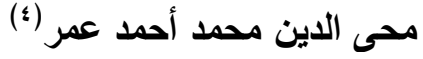

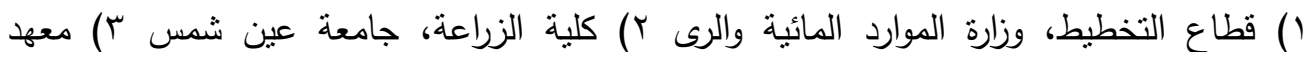

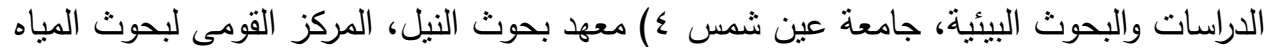

\section{المهريلص}

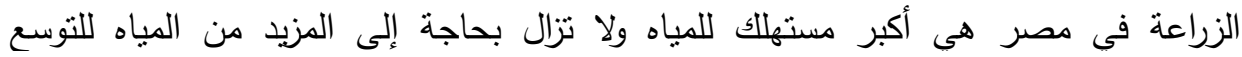

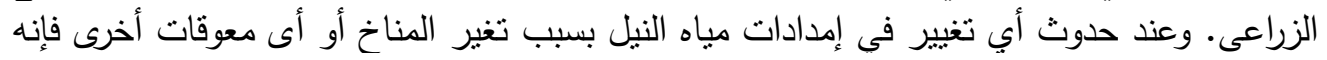

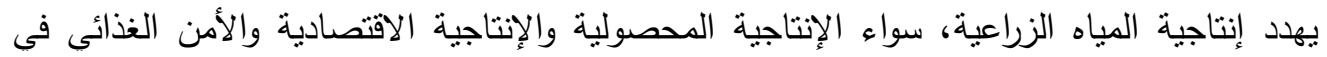

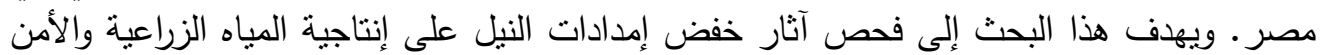

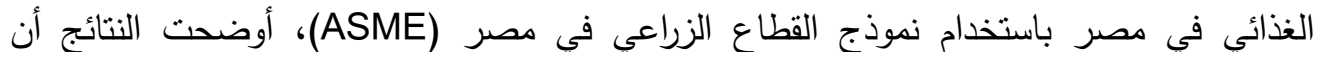

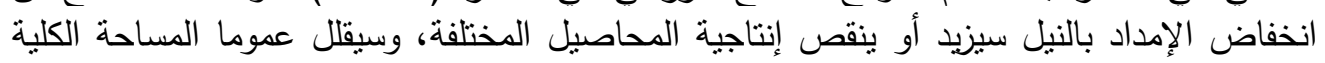

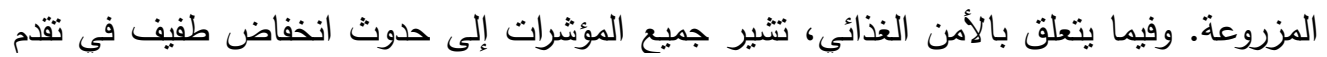

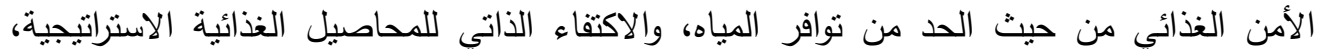

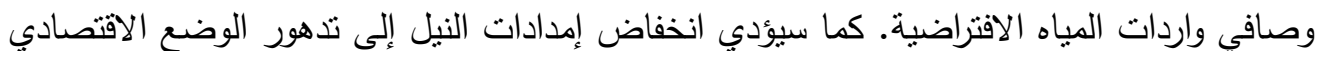

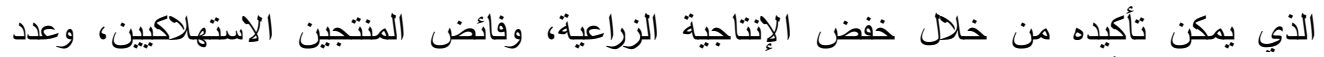

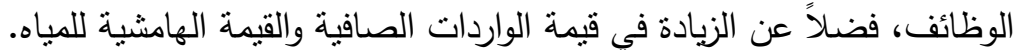
توصي الدراسة بتتفيذ تدابير التكيف من أجل الاستخدام الفعال للموارد الماردانية المائية المتاحة وزيادة

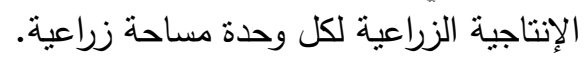
كلمات البحث: ASME ، الإنتاجية الزراعية ، تغير المناخ 